\title{
TEACHING UKRAINIAN FOLK DUMAS AT UNIVERSITY: ANALYSIS IN CONTEXT OF INTERCULTURAL COMMUNICATION
}

\author{
Maryna Nabok \\ Sumy State University, Sumy, Ukraine \\ nabok.marinka@gmail.com
}

\begin{abstract}
The article deals with the basic principles of teaching Ukrainian folk dumas in higher educational institutions of Ukraine. Based on the principles of teaching Ukrainian folk dumas in higher educational institutions of Ukraine, we conducted an experimental study with further comparative analysis of the perception of dumas by Ukrainian and foreign students. We used the method of interview (including written feedback from students). The research was conducted in groups of Ukrainian and international students (from Africa and the Middle East) who studied at Sumy State University (Ukraine). 100 respondents aged 19-22 were interviewed. Students listened to audio recordings of Ukrainian folk dumas, analysed texts and gave written feedback about the perception of epic heroes and dumas in general. The results we obtained showed that teaching Ukrainian folk dumas based on the principle of close connection of teaching with the modern life of society and the principle of family-centrism helps students from different countries and cultures to recognise themselves as successors of traditions that form their spiritual world, an active life position and national identity in the context of modern globalisation processes. The use of these principles in teaching dumas promotes the students' individual perception of the learning content, reveals national specifics of the student's world outlook, deeply rooted in the genetic memory of generations and national psychology.
\end{abstract}

Keywords: new principles of teaching; Ukrainian folk duma; educational process; intercultural communication process; professional competence; cross-cultural research; cooperation.

\section{Introduction}

In the context of modernisation processes which take place in the educational sphere, there is a need for innovative changes in the study of Ukrainian folk dumas in higher educational institutions of Ukraine. Ukrainian folk dumas is a genre of Ukrainian oral folk art; lyric-epic songs about historical or social events in Ukraine. This genre arose in the $15-16^{\text {th }}$ centuries, but as a phenomenon of Ukrainian epic arts dates back to the times of Kyiv Rus (9-13 ${ }^{\text {th }}$ centuries), or possibly even earlier. Historically, Ukrainian folk dumas were performed by highly professional folk singers - kobzars or bandura-players to the accompaniment of kobza, bandura or lira (Ukrainian national string musical instruments). These folk songs told people not only about various events, but also about the values of freedom and independence, family values, devotion to homeland. Ukrainian folk dumas affirm humanistic ideals, high moral principles of the Ukrainian people.

This genre of folklore is studied by Ukrainian and international students of philological specialities within the discipline of "Ukrainian Folklore" (its variants: "Folklore", "Ukrainian Oral Folk Poetics", "Ukrainian Oral Folk Poetic Arts") as well as the author's special courses. This study is part of the comprehensive research conducted with international students at the Department of Language Training of Foreign Citizens.

The purpose of our research is to characterise the basic principles of studying Ukrainian folk dumas and based on these principles to conduct an experimental study with further comparative analysis of the perceptions of dumas by Ukrainian and international students.

\section{Literature review}

Issues of the history of Ukrainian folk dumas were investigated by Kolessa (1969), Kyrdan (1962), Franko (1986) and others. Theoretical foundations of the study of Ukrainian folk dumas were analysed by Lanovik and Lanovik (2001). Features of poetics, musical form of dumas were explored by Grutsa (2007). Rusnak (2010) provided a detailed analysis of the theoretical foundations of the genre of folk dumas. Nudga (2006) presented numerous reviews of non-Ukrainian researchers about our folk poetics. In particular, he noted that for an ordinary citizen of Holland as well as for professional musicians, Ukrainian folk dumas and songs opened a new world of magic melodies. The history of folklore, genre theory, the problems of "folklore and symbol", "folklore and literature" were discussed by Dmytrenko (2001). This author also studied the problems of the aesthetically developed personality in Ukrainian dumas (Dmytrenko, 2011). The

(C) Nabok, M. 2020. Published by Igor Sikorsky Kyiv Polytechnic Institute.

This is an Open Access article distributed under the terms of the licence CC BY 4.0 
national identity of an epic hero of folk dumas and its typology were investigated in Nabok's (2014) monograph "Ukrainian folk dumas: features of the national character and typology of the hero".

Cross-cultural education contributes to understanding and acceptance of cultural differences, ethnic tolerance, which is particularly important in the university environment with its close intercultural communication and interaction (Czepil et al., 2019, p.118). The creative interaction between the teacher and the student allows "deeper study of Ukrainian dumas' role in the formation of the national identity during intercultural communication" (Nabok, 2018, p. 199) and is an integral part of the organisation of creative education (Tsvetkova, 2016). The issues of the integration of art into the educational process in the United States are discussed in the works of Dowell and Goering (2018), Bautista et al (2016).

\section{Methods}

To teach Ukrainian folk dumas at Sumy State University we used the method of the interview (including written feedback from the students). We applied the following principles in teaching dumas to Ukrainian and international students (Nabok, 2018; Nabok \& Saeb, 2019):

1) the principle of close connection of teaching with the modern life of Ukrainian society;

2) the principle of family-centrism.

The survey involved 100 Ukrainian and international students from Africa (Nigeria, Ghana, Tanzania) and countries of the Middle East (Jordan, Palestine, Iraq, Turkey) aged 19-22 years. For this, we invited the students to listen to the records of folk dumas "Cossack Golota", "Marusya Boguslavka", "Crying of the Slaves", "Ivan Konovchenko", "Three Brothers of Samara" and to express their attitude to the heroes of dumas as also to characterise the symbolism of folk works. After listening and analysing these dumas, we asked students to answer questions and write feedback reviews. Participation in the survey was voluntary and students agreed to publish the results without indicating their names. The questions were as follows: 1) describe the main characters of dumas (their desires, motives for action, ideas, etc.); 2) describe the symbolic system of dumas; 3) which dumas do you like most and why? 4) do you like bandura music? 5) what associations does this music cause?

One of the most important principles of teaching Ukrainian folk dumas is the principle of the close connection of teaching with the modern life of Ukrainian society. Learning and analysing dumas should help students to determine their life position and realise their importance in the life of the nation at the present stage of its development.

Using of the principle of close connection of teaching with the modern life of Ukrainian society makes the educational process deeply individualised. Analysing dumas students determine the nature of emotions of the characters, comparing their manifestations in various genres of folklore. A lecturer brings students' attention to the features of the Ukrainian national outlook as the basis for the formation of the spiritual values of the nation. It promotes students' abilities to analyse and generalise, helps to involve them as equal participants in the educational process.

In complex with the principle of close connection of teaching with the modern life of Ukrainian society, we used the principle of family-centrism. Throughout the Ukrainian history, family-centrism was the basis of the educational process. In the creative cooperation of a student and a teacher, the atmosphere of mutual understanding was created which activated the learning process. The perception of kobzars' performances of dumas by Ukrainian and international students was to a certain extent determined by features of national character.

Thus, when teaching Ukrainian folk dumas a lecturer should familiarise students with the personalities of the creator and the performer of dumas as bearers of the national character of Ukrainians. It is important that students perceive themselves as continuers of national traditions, form their own spiritual world and an active life position preserving the national values in the conditions of modern globalisation processes.

\section{Results}

After discussion and analysis of Ukrainian folk dumas, students answered questions and wrote reviews about their attitude to heroes of dumas, characterised the symbolic system of folk works. Ukrainian students perceive the heroes of Ukrainian folk dumas "Cossack Golota", "Ivan Konovchenko" in the context of the war in Eastern Ukraine. For example, one of the students wrote, 'The images of cossack Golota and Ivan Konovchenko are close to the images of modern heroes who today defend the borders in Eastern Ukraine'. 'The image of kobzar, his singing, facial expressions, gestures, intonation, pauses create a special world, because I feel a strong flow of energy. Emotions overflow', wrote another Ukrainian student. 
The heroes of the Ukrainian Dumas are also close to Arab and Turkish students, because they have similar associations with their national heroes. A student from Iraq wrote, 'I understand their desire for freedom. I am always ready to give my life for my homeland, because this is my land and my people'. Students from African countries pay attention to the poor clothes of the Cossack Golota and his attitude to the battlefield as a living being. The cossack's address to the field is a feature of the pre-Christian religion of Ukrainians, when man and nature were perceived as a whole. In his feedback, a student from Ghana stated, "Heroes of dumas are very brave and emotional, so they are like us". Thus, Ukrainian and foreign students sympathise with the heroes of the dumas, rejoice in the victories of the cossacks, which indicates their understanding of the concepts of "good - evil", "beautiful - ugly", "freedom - slavery", "honour - dignity".

A student from Ukraine, for example, wrote, "When kobzar performs dumas, he takes us back to our origins - the times when Cossacks, our heroic ancestors, struggled for the Ukrainian State. The sound of his bandura creates a spiritual Ukrainian atmosphere, in which you feel like a real Ukrainian. It's at the genetic level!" Students from Africa wrote that in the harmonious combination of words and music in Ukrainian dumas they felt Ukrainian national sole. Deeply aesthetic feelings were expressed in feedback by a student from Tanzania who wrote: "In my opinion, such performances are unique and, probably, traditional for Ukrainians". This understanding of African students is based on the specifics of their national perception, their subtle sense of words, sounds, melodies.

The students from the Middle East associated the image of a kobzar with their national singers. In the ancient Arab tradition, there were singers-poets "shairi" (الثاعر) called "prophets" who sang about the exploits of soldiers. There were also other genres of songwriting such as a "song-challenge to battle" (أرجوزة), a "song-revenge", (انتصار), "praise song" (مدح). Therefore the kobzar's performance of folk dumas evoked students' associations with their folk performers. A student from Jordan wrote: "The kobzar combined playing the bandura with movements, and I liked it. I felt the strength and believed that I could do something extraordinary. His performance feels the whole space with the powerful flow of energy". Listening to dumas evoked the genetic connection with the students' native land and family. Describing his emotions one of them wrote: "When I first heard this duma, I felt like a flying bird. I wanted to fly to Palestine. I really miss it".

Students from Turkey, when listening to dumas performed by kobzars, felt the power of their ancestors. Playing a musical instrument, especially during the Ottoman Empire, was very important. Loudly playing a musical instrument, a singer (turk. Hanende) talked about the future military campaign or the victory of the Turks in a war. Therefore, playing the Ukrainian bandura reminded them of the military campaigns of their brave ancestors. For example, one Turkish student wrote, "In ancient times we also had street performers who played Kopuz, Bağlama or Saz (Turkish folk instruments) and sang songs about national heroes". Another student added, "It is important for a Turkish soldier not just to be brave, but to become more and more brave during his life. That is why for me Ukrainian cossacks Golota and Ivan Konovchenko associate with our brave national heroes".

$60 \%$ of Ukrainian students perceive heroes of the dumas as defenders of their native land, for whom Cossack glory is higher than material status ("Cossack Golota", "Ivan Konovchenko", "Three Brothers of Samara"). After all, Ivan Konovchenko, the only son of his mother, abandons careless life, goes to gain Cossack glory and dies as a hero. The image of the Cossack Golota and the image of the field are viewed holistically by students because the field for the Cossack is his friend who supports and rejoices with him in victory. Three Brothers of Samara died in the field as heroes and supported each other to the end. Students note that the images of heroes of dumas "Cossack Golota", "Ivan Konovchenko", "Three Brothers of Samara" are close to the images of modern heroes who are fighting in Eastern Ukraine. Students perceive the image of the field not as an archetype of "fertile land" but as a symbol of victory. $40 \%$ of all respondents most of all liked dumas about slavery ("Crying of the Slave", "Marusya Boguslavka"), $18 \%$ students - the duma "Crying of the Slave", 22\% - "Marusya Boguslavka". Students sympathise with the heroes of these dumas, who were suffering in prison for many years. They liked the duma "Marusya Boguslavka" most because the girl Marusya released her compatriots to freedom.

Students from countries of Africa listened and analysed folk dumas of the slave cycle - "Marusya Boguslavka", "Crying of Slaves" and folk dumas of the heroic cycle - "Cossack Golota", "Ivan Konovchenko", "Three Brothers of Samara". They wrote essays on their attitudes to the characters' actions, the symbolic system of dumas. $50 \%$ of African students perceive the characters as defenders of their land. Music, rhythm, exclamations, characters' appeals to God played an important role in this perception. One student from Nigeria wrote that the brothers (duma "The Three Brothers from Samara") who left their home together to defend their land, is an example to follow. $50 \%$ of students liked dumas about the slaves most of all. They admired Marusya Boguslavka's courage, paid attention to the musical rhythm. One student from 
Tanzania, for example, felt the beauty of the inner world of Ukrainians in the Ukrainian melodies, which he listened to more than once. He, as a medical student, suggested that Ukrainian melodies should be used for patients of neurological departments, in general therapy, because they are full of optimism, pleasant, calm fascinating sounds.

We have different results in groups of students from the Middle East (Jordan, Palestine, Iraq). In these empirical studies, we note that students from Iraq admire the heroic struggle of the Cossacks for their native land in Ukrainian folk dumas. For them, it is especially close and understandable, because it makes them reflect on their own destiny and the fate of their people. The weapons, the horses, are the symbols of victory in dumas. Thus, $100 \%$ of Arabic students prefer the dumas of the heroic cycle: "Cossack Golota", "Ivan Konovchenko", "Three Brothers of Samara". 83\% of Arabic students liked the duma "Marusya Boguslavka" most of all. Many of them perceived Marusya Boguslavka as a traitor because she released the slaves without the consent of the Sultan. However, $20 \%$ of these students were amazed at her courage. The students from Jordan were inspired by the brave action of the girl Marusya (the duma "Marusya Boguslavka"). For them, it is an example to follow. For example, one of the students wrote: "We in Jordan have songs which glorify the images of a king, a general, a leader, but not ordinary people. However, Ukrainians keep in memory the exploits of the glorious cossacks, glorify them in songs. Not only men, but also girls are brave". Analysing the folk duma the student concluded that this duma must be studied at school. By the way, Middle Eastern researchers point to similar national manifestations of character. In particular, they identify five cultural characteristics of the Arab people: "a high level of religiosity, morality (i.e., respect, humility, and fairness), the culture of honour tightly linked to reputation, generosity and hospitality, and family values" (Gadelrab et al. 2018, p. 2). 17\% of Arabic students preferred "Crying of Slaves" duma. One student wrote, "I like this duma because I am sentimental in nature".

The results we obtained in the interview of students from Turkey are mostly similar. 100\% of respondents most of all liked the dumas of the heroic cycle ("Cossack Golota", "Ivan Konovchenko", "Three Brothers of Samara"). In their comments, they noted that Turks, like Ukrainians, are also very brave. Like students from Africa and the Middle East, the Turkish students paid attention to the performance of folk dumas by the kobzars. They wrote that in Turkey they also had folk performers like kobzars who played Bağlama or Saz (Turkish folk instrument which appeared in the 18th century and is still played today). Their task was to show people the bravery of warriors, the importance of military campaigns for the future of the empire. That is why the performance of folk dumas by kobzars is close and understandable for students from Turkey as a symbol of unity of generations. $80 \%$ of respondents preferred the duma "Marusya Boguslavka". If most Arabic students perceive her as a traitor and therefore did not trust the girl, the Turkish students perceived her as a brave woman who was loyal to her Sultan because she did not run away with the slaves. $15 \%$ of the students predicted that the Sultan would punish his wife. The rest of the respondents believed he would understand this act and forgive her, because he loved her. $20 \%$ of students from Turkey liked the "Crying of Slaves" duma because they admired bandura playing which returned them in their thoughts to their homeland.

\section{Discussion and conclusion}

As shown by our research intercultural comparative studies are important for understanding the national specifics of perception of literary texts by representatives of different cultures. In the process of intercultural communication, students learn a foreign culture, evaluate socially normalised habits, traditions, customs of other peoples through the prism of their own culture, exchange opinions and ideas. In this respect, crosscultural education helps to build up understanding between representatives of different nations, develop tolerance to cultural and ethnic differences, create a platform where common values and aspirations unite young people from different parts of the world.

Teaching Ukrainian folk dumas based on the principle of close connection of teaching with the modern life of society and the principle of family-centrism helps students from different countries and cultures to recognise themselves as successors of traditions that form their spiritual world, an active life position and national identity in the context of modern globalisation processes. For students from African countries, the characters of Ukrainian folk dumas are examples of the spiritual culture of an individual. They pay attention to the close relationship between man and nature, the deeply emotional inner world of the characters. The students even believe in the healing powers of Ukrainian melodies because they are full of optimism, pleasant, calm, fascinating sounds. For Arab students, dumas are close because they reflect the values which are coherent with the values of their cultures: heroism, religion, family ties, respect for authority, appreciation of ethnic unity and self-sacrifice. Turkish students express their respect to the characters of dumas and highly appreciate their feelings of conscience, duty, honour, responsibility, dignity. The melodies 
of dumas deeply affect their feelings and mentally return them to their native land, brave ancestors and homes.

\section{Acknowledgements}

I would like to express my sincere gratitude to foreign students of Sumy State University who agreed to participate in our study. I am grateful to them for their interest in folk art, folk psychology, the Ukrainian language, and the history of Ukraine. Special thanks to Mintah-Benyin Kwesi Gyebi, Alhassan Hafsat Ojonugwa, Odewole Oluwadamilola for the stylistic and grammatical editing of this article.

\section{References:}

Bautista, A., Tan, L.S., Ponnusamy, L.D., \& Yau, X. (2016). Curriculum integration in arts education: connecting multiple art forms through the idea of 'space'. Journal of Curriculum Studies, 48, 610-629. https://doi.org/10.1080/00220272.2015.1089940

Czepil, M., Karpenko, O., Revt, A., \& Istomina, K. (2019). Formation of students' ethnic tolerance in institutions of higher education. Advanced Education, 12, 114-119. https://doi.org/10.20535/2410-8286.168675

Dmytrenko, M. (2001). Ukrai'ns'ka fol'klorystyka: istorija, teorija, praktyka [Ukrainian folkloristics: history, theory, practice]. Kyiv: Narodoznavstvo.

Dmytrenko, M. (2011). Symvoly Ukrai'ns'kogo Fol'kloru [Symbols of Ukrainian Folklore]. Kyiv: UTsKD.

Dowell, M-M.S. \& Goering, C.Z. (2018). Editors' introduction: On the promise and possibilities of arts integration in education. Pedagogies: An International Journal, 2, 85-91. https://doi.org/10.1080/1554480X.2018.1449180

Franko, I. (1986). Studii' nad ukrai'ns'kymy narodnymy pisnjamy [Studies on Ukrainian folk songs]. Kyiv: Naukova dumka.

Gadelrab, H.F. \& Alkhadher, O, Aldhafri, S. \& Almoshawah, S., Khatatba, Y. \& El Abiddine, F.Z. ... \& Slimen, S. (2018). Organizational Justice In Arab Countries: Investigation of the Measurement and Structural Invariance. Cross-Cultural Research, 10, 1-25. https://doi.org/10.1177/1069397118815099

Grutsa, C. (2007). Ukrai'ns'ki narodni dumy [Ukrainian folk dumas]. Kyiv: IMFE NAN Ukrai'ny.

Kolessa , F. (1969). Melodii' ukrai'ns'kyh narodnyh dum [Melodies of Ukrainian folk dumas]. Kyiv: Naukova dumka.

Kyrdan, B. (1962). Ukrainskie narodnye dumy (XV - nachalo XVII v.) [Ukrainian folk dumas (XV - beginning of the XVII c.)]. Moscow: USSR Academy of Sciences.

Lanovyk, M. \& Lanovyk, Z. (2001). Ukrai'ns'ka usna narodna tvorchist' [Ukrainian oral folk art]. Kyiv: Znannja-Pres.

Nabok, M. \& Saeb, A. (2019). Ideja Rodu v ukrai'ns'kyh narodnyh dumah nevil'nyc'kogo cyklu ta arabs'komu fol'klori [The idea of Genus in Ukrainian folk dumas about captivity and in Arabic folklore]. In O. Novikova, Schweier, Ulrich (Eds.), Dialog der Sprachen - Dialog der Kulturen. Die Ukraine aus globaler Sicht. IX. Internationale virtuelle Konferenz der Ukrainistik, München, 1.-4. November (pp. 164-175. München: Universitätsbibliothek der Ludwig-Maximilians-Universität.

Nabok, M. (2018). Ukrainian National Dumas: National Perceptions in the Process of Intercultural Communication. Psycholinguistics, 24(2), 198-217. https://doi.org/10.31470/2309-1797-2018-24-2-198-217

Nabok, M., (2014). Ukrai'ns'ki narodni dumy: osoblyvosti nacional'nogo harakteru i typologija geroja [Ukrainian Folk Dumas: Peculiarities of the National Character and Typology of the Hero]. Ternopil': Pidruchnyky i posibnyky.

Nudha, H. (2006). U koli svitovoi' kul'tury [In the Circle of World Culture]. Lviv: l'vivs'kyj nacional'nyj universytet imeni Ivana Franka.

Rusnak I. (2010). Ukrai'ns'kyj fol'klor [Ukrainian folklore]. Kyiv: Akademija.

Tsvietkova, H. (2016). Innovacijnist' jak pryncyp novogo pedagogichnogo myslennja ta shljah profesijnoi' samorealizacii' vykladachiv gumanitarnyh dyscyplin [Innovativeness as a principle of new pedagogical thinking and a way of professional self-realisation of teachers of humanitarian disciplines]. Vyshcha osvita Ukrainy, 1, 42-48. https://wou.npu.edu.ua/images/arhiv/2016/01/Binder9.pdf 